\title{
A National Security Study of Unisplendour's Attempted Western Digital Acquisition
}

\author{
Chanting Chen ${ }^{1, \text { a }}$ \\ ${ }^{1}$ East China University of Political Science and Law, Shanghai, China \\ âchenchanting@126.com
}

Keywords: Semiconductor, National Security, FINSA, CFIUS

\begin{abstract}
This paper studies the Unisplendour's failed acquisition of Western Digital from the perspective of national security. It starts with the introduction of the aborted transaction, which is followed by the explanation of the nature and procedure of national security review. The third part of the article analyzes potential national security concerns the case might bring, including the sensitivity of semiconductor industry, the Chinese nationality and governmental background of the acquirer, and the possible loss of U.S.' leadership in the semiconductor industry. The last part of the paper predicts that there will be more rigorous security review to Chinese investors and sensitive industries in future.
\end{abstract}

\section{Unisplendour's failed attempt of acquiring WD}

In September 2015, during the Sino-US Internet Conference, Unigroup and Western Digital (WD) released a cooperation statement, saying that Unisplendour Corporation Limited, a wholly owned subsidiary of Unigroup, would subscribe WD's newly issued 40.8148 million shares, with the price of $\$ 92.5$ per share. The total amount of transaction would be $\$ 3.775$ billion, about 24 billion RMB. Prior to the transaction, the shareholding proportion of WD shareholders is comparatively dispersed. Those shareholders are mainly institutional investors, and there are no proprietary shareholders or actual controllers. If the transaction was completed, Unigroup would hold about 15\% shares of WD, become WD's largest shareholder, and have one board seat within WD. Chinese related domestic industries and capitals had great expectations for the acquisition. The Ministry of Commerce also responded positively to the acquisition. [1]

Despite of the high expectation, on February 23, 2016, the company received a written notice from the Committee on Foreign Investment in the United States (CFIUS), requiring the transaction to accept the Committee's national security review. According to the two parties' Subscription Agreement, either party had the right to terminate the Agreement if CFIUS asked for national security review to the deal. In view of the above, the board of directors of Unigroup decided to terminate the transaction. This is Unigroup's second failed attempt to buy U.S. counterparts. The first one was in 2014, when Unigroup had planned to acquire Micron Technology, U.S. largest memory chip company, with $\$ 23$ billion transaction price. Micron concerned that the business might be rejected by CFIUS, and turned down the bid. [2]

\section{The nature and working procedure of CFIUS review}

CFIUS is an inter-agency committee specifically for reviewing foreign investment and evaluating its effect on national security. The committee is composed of the secretaries of treasury, commerce, state, defense, energy and homeland security, the attorney general, and two ex officio members served by the director of national intelligence and the secretary of labor. The legal foundation of the review is the Foreign Investment and National Security Act of 2007 (FINSA), enacted by Gorge W. Bush government. The act is the successor of the well-known Exon-Florio Amendment. It inherits and develops the Exon-Florio Amendment's attitude towards inbound FDI and develops review and investigation process.

FINSA reiterates that the State is not hostile to foreign investment, and the security review 
mechanism is not for scaring away foreign capital. The act explains that examination of foreign investment is for "promoting foreign investment and the creation and maintenance of jobs" with the security of the country as a precondition. [3] FINSA endows the president refusal power only when he finds there is no other laws, except the International Emergency Economic Powers Act, can protect the country's security. This statement reveals the nature of national security review as the last resort to ensure the nation's security in foreign investment domain.

As for what is national security, FINSA follows the Exon-Florio Amendment's practice, refusing to define the term. Lawmakers consider it impossible to list all situations involving national security. Instead, FINSA lists ten consideration factors. Accordingly, businesses requiring national security reviews are those related to national defense, high technologies and critical infrastructure. Also, home country government background of the acquirers is within the consideration, i.e. the government's connection with terrorism, and proliferation of missile and biochemical weapons, the government's involvement of the transaction, the government's endeavor in nonproliferation and counter-terrorism. FINSA also gives the discretion of recognition of national security to President and CFIUS, who are authorized to define the national security on a case-by-case basis when they consider as appropriate. [4]

The national security review is formally consists of three steps, the review, the investigation and the presidential decision stages. The review stage is initiated either by transaction parties' voluntary notification or by the President or any member of CFIUS. The former option is recommended. Once a transaction is approved by CFIUS, most of time it will not be checked again once the transaction is completed. The review procedure lasts maximum 30 days. CFIUS completes its review based upon jointly provided transaction information, including views of the Director of National Intelligence. [5] If all of CFIUS members find that the transaction does not impair or threaten to impair the country's security, the review is terminated. However, if any one member of CFIUS thinks that the business has negative impact to the national security, the Committee will proceed to the investigation stage. Besides finding of threat during the review stage, the investigation stage will be initiated if the foreign company is controlled by a foreign government.

The investigation period lasts 45 days. At the conclusion of this stage, if CFIUS affirms the threat, it will submit the case to the President and recommend the President to suspend or prohibit the investment. The president will have 15 days to make his determination. The President has almost unlimited authority to take "such action for such times as the President considers appropriate to suspend or prohibit any covered transaction that threatens to impair the national security of the United States.” The finding of the President is not subject to judicial review. [6]

Before the initiation of CFIUS process, there is an informal preliminary review process. This preliminary process provides an unspecified length of time for CFIUS to find out necessary information and make an unofficial determination even before the formal process begins. [7] It is suggested that transaction parties to take advantage of the informal process to work out security problems privately with individual CFIUS members, without "potential negative publicity that could arise if a transaction were to be blocked or otherwise labeled as impairing U.S. national security interests." [8] In the Unisplendour - WD case, while the precise feedback is kept as a business secret, the two parties of the transaction might have received some negative evaluations from CFIUS in the preliminary review process based on the information published by the media.

\section{National Security Analysis of Unisplendour - WD Case}

\section{(1) National Security Concern over Semiconductor Industry}

The transaction between Unisplendour and WD is sensitive for national security purpose due to the nature of business, semiconductor manufacturing industry, which the US federal government has been actively involved in. Governmental close attention is because of the linkage between the industry and national security. There are arguments that due to the wide application of semiconductor products in military, dependence on foreign semiconductors manufacturer would adversely affect the country's military and national defense capabilities, especially when the 
country has to depend on those manufacturers from hostile countries or regions. [9]

At the beginning of this year, the President's Council of Advisors on Science and Technology (PCAST) issued Ensuring Long-term U.S. Leadership in Semiconductors. According to the Report, semiconductors are very important to modern U.S. for they will bring about new devices and services, more massive benefits to U.S. workers and consumers. Also, leading-edge semiconductor technology is essential to defense systems, military strength and cyber security. [10] The transaction therefore is within consideration factors as listed by FINSA.

(2) National Security Concern Regarding Businesses from China

Besides to the significance of the semiconductor industry to national security, national security concern regarding the Unisplendour - WD transaction is also due to the fact that the acquirer Unisplendour is a Chinese company. The distrust comes from ideological and state system differences, national strength competition and most importantly the rapidly growing Chinese acquisitions in the U.S. Based on data provided by CFIUS, Chinese investors were the most active ones in mergers and acquisitions during the year 2012 to 2014. Accordingly, China is the top country of origin for investors providing notifications to CFIUS. [11] (Table I)

Table I Country of Foreign Investor and Industry Reviewed by CFIUS, 2012-2014

\begin{tabular}{|c|c|c|c|c|c|}
\hline Country & Manufacturing & $\begin{array}{l}\text { Finance, } \\
\text { Information, } \\
\text { and } \\
\text { Services }\end{array}$ & $\begin{array}{l}\text { Mining, } \\
\text { Utilities, and } \\
\text { Construction }\end{array}$ & $\begin{array}{l}\text { Wholesale } \\
\text { Trade and } \\
\text { Retail } \\
\text { Trade }\end{array}$ & Total \\
\hline China & 33 & 13 & 19 & 3 & 68 \\
\hline $\begin{array}{l}\text { United } \\
\text { Kingdom }\end{array}$ & 20 & 16 & 5 & 4 & 45 \\
\hline Canada & 4 & 6 & 20 & 10 & 40 \\
\hline Japan & 18 & 10 & 5 & 4 & 37 \\
\hline France & 12 & 8 & 0 & 3 & 21 \\
\hline Germany & 10 & 7 & 0 & 0 & 17 \\
\hline Switzerland & 13 & 2 & 0 & 0 & 15 \\
\hline Netherlands & 4 & 9 & 2 & 0 & 15 \\
\hline Singapore & 2 & 3 & 3 & 3 & 11 \\
\hline Israel & 8 & 2 & 0 & 0 & 10 \\
\hline $\begin{array}{l}\text { South } \\
\text { Korea }\end{array}$ & 4 & 4 & 2 & 0 & 10 \\
\hline Total & 151 & 106 & 68 & 33 & 356 \\
\hline
\end{tabular}

Source: Annual Report to Congress, Committee on Foreign Investment in the United States, February 2016.

In addition, according to the data provided by Morning Whistle Group, the US has been the first destination of Chinese overseas acquisitions and the number of acquisition has been increased rapidly to reach almost 400 since 2014. [12] In the face of the increasing acquisition numbers, members of the U.S. House of Representatives and Senators find that Chinese investment is circumventing CFIUS to control U.S. assets and CFIUS is outdate and ill-equipped to handle these new situations. They therefore have repeatedly called for a more rigorous review of investment from China, and for a revision of FINSA to strengthen CFIUS power. [13] U.S. Congressional Economic and Security Review Committee also submitted its 2016 annual report, suggesting Congress amend FINSA to grant CFIUS the power to prohibit Chinese state-owned enterprises from acquiring U.S. corporate assets or obtaining effective control of U.S. companies. [14]

(3) National Security Concern Regarding Government-related Companies

According to FINSA, foreign government-controlled transactions would receive national security review automatically. The rationale is that it would be difficult to tell whether an acquisition decision is out of a corporate strategy or a government policy. Code of Federal Regulations Part 800 defines foreign government-controlled transaction as "any covered transaction 
that could result in control of a U.S. business by a foreign government or a person controlled by or acting on behalf of a foreign government.” [15] Unisplendour is a Tsinghua University owned company working on improving the industrialization of scientific and technological achievement. Tsinghua University is directly under the Ministry of Education of the PRC. Because of the affiliation of Unisplendour to Chinese government, the Unisplendour-WD transaction may be considered as Chinese-government-controlled company according to the previous definition.

Another reason to treat government-sponsored companies differently is that they compete on a preferable basis as those without such background. [16] Government-sponsored companies may have preferential treatment in financial support and market access. Too much government support may conflict with and destroy the free market and fair competition principles which the U.S. considers as central pillar of the nation's economic system. Therefore, government-sponsored transaction is regarded as potentially dangerous to the country, so they have to receive stricter scrutiny from CFIUS.

(4) Threaten to U.S.’ Leadership in Semiconductor Industry

The report points out that cutting-edge semiconductor technology is very important U.S. defense systems and military strength. It is therefore crucial to maintain U.S. leadership in semiconductor industry, which requires an open, market-based environment to inspire innovation. The report mentions that though market forces is a central and critical role in this process, the U.S. government needs to "confront challenges from changing technology at the same time as it faces a new and aggressive set of Chinese industrial policies designed to shift the competitive dynamics in the global industry in favor of Chinese production and companies.” [17]

In consideration of the necessity of the transition of China's economic development and the key role of the semiconductor industry in modern industrial upgrading, the Chinese government has issued a series of related policies to promote the development of the semiconductor industry in recent years. Take for example, the 13th Five-Year Plan puts forward that government should support the development of information technology and high-end equipment and materials, so as to assist the improvement of strategic emerging industries. [18] The "Made in China 2025", China's latest industrial policy, regards semiconductor industry as crucial to be improved. Also, the Outline for Promoting Development of National Integrated Circuit Industry and the National Integrated Circuit Industry Investment Fund jointly promote the sale of semiconductor products.

From U.S. perspective, previous Chinese industrial policies intend to achieve a global leadership position in semiconductor industry through non-market means. U.S. holds that these policies will benefit Chinese semiconductor producers and consumers alike, and may pose threats to semiconductor innovation and leadership. This could be considered as a negative impact to U.S. national security.

\section{More rigorous security review to Chinese investors and sensitive industries in future}

A considerable number of CFIUS staffs have expressed support for CFIUS reform. Analysts say that Senator Cornyn's proposal has received approval from many Administration officials. The proposal might includes four major changes, including to expand CFIUS's jurisdiction to review non-control transactions and to add a list of countries of concern. [19] Senator Cornyn has already suggested putting China into the list of countries of concern. It is therefore foreseeable that Chinese enterprises will have more contact with CFIUS if they decide to invest in U.S.

In addition, sensitive industries will receive intense scrutiny. FINSA lists ten consideration factors for the President and CFIUS to decide whether a covered transaction constitutes threats to the State. These factors indicate that industries related to defense, high technologies, military goods, critical infrastructure, crucial resources and material will be considered as with national security significance. Businesses involving these industries are going to keep on receiving intense scrutiny from CFIUS. In the specific case of semiconductor industry, more and stricter CFIUS scrutiny is predictable. The PCAST in the Ensuring Long Term US Leadership in Semiconductors suggests to "[r]eshape the application of national security tools, as appropriate, to deter and respond forcefully 
to Chinese industrial policies.” [20] Senator Cornyn, in his effort to call for CFIUS reform, also raised concerns on Chinese investment in semiconductor technologies. [21]

Chinese investors should neither ignore nor fear CFIUS and national security review. It is strongly recommended that they hire professional CFIUS lawyers and reach an agreement with the U.S. business party on CFIUS review issue. It is also advisable that there are more high-level talks on investment between leaders of U.S. and China, so as to create a friend climate for bilateral investment.

\section{References}

[1] Zilin Wang, Unisplendour stops to buy WD, Shanghai Securities News, 2016 Edition F06, Feb. 24.

[2] Yan Ma, Unisplendour stops to buy WD due to foreign investment risks, Securities Daily, 2016 Edition C03, Feb. 24.

[3] Foreign Investment and National Security Act of 2007, public law 110-49-July 26, 2007.

[4] 50 USCS Appx 2170 (f).

[5] James K. Jackson, the Committee on Foreign Investment in the United States (CFIUS), 2016 p19.

[6] 50 USCS Appx 2170 (d), (e).

[7] James K. Jackson, the Committee on Foreign Investment in the United States (CFIUS), 2008 pp. $10-11$.

[8] Ibdi, at p19.

[9] Michaela D. Platzer, John F. Sargent Jr., U.S. Semiconductor Manufacturing: Industry Trends, Global Competition, Federal Policy, p21.

[10] President's Council of Advisors on Science and Technology, Report to the President: Ensuring Long-Term U.S. Leadership in Semiconductors, p2.

[11] James K. Jackson, the Committee on Foreign Investment in the United States (CFIUS), 2016 pp 26-27.

[12] US plans to revise CFIUS functions, more disadvantages for Chinese investors, available at https://www.jiemian.com/article/1360669.html, last visited on Aug. 20, 2017.

[13] See Update on CFIUS Developments: Proposed Legislation and Reflections on CFIUS Under the Trump Administration, available at https://www.cov.com/-/media/files/corporate/publications/2017/06/update_on_cfius_developm ents_proposed_legislation_and_reflections_on_cfius_under_the_trump_administration.pdf, last visited on Sept. 10, 2017.

[14] US plans to revise CFIUS functions, more disadvantages for Chinese investors, available at https://www.jiemian.com/article/1360669.html, last visited on Aug. 20, 2017.

[15] 31 CFR $§ 800.214$

[16] See James K. Jackson, The Committee on Foreign Investment in the United States (CFIUS), 2016 p14.

[17] President's Council of Advisors on Science and Technology, Report to the President: Ensuring Long-Term U.S. Leadership in Semiconductors, p6.

[18] The $13^{\text {th }}$ Five-Year Plan, available at http://sh.xinhuanet.com/2016-03/18/c_135200400_5.htm, 
last visited on August 21, 2017.

[19] Update on CFIUS Developments: Proposed Legislation and Reflections on CFIUS Under the Trump Administration, p 2.

[20] President's Council of Advisors on Science and Technology, Report to the President: Ensuring Long-Term U.S. Leadership in Semiconductors, p 13.

[21] Update on CFIUS Developments: Proposed Legislation and Reflections on CFIUS Under the Trump Administration, pp 1-2. 